\title{
A haunting message for unethical doctors
}

\author{
HARSHAL TUKARAM PANDVE
}

Kanika, Director: Pushkar Manohar, Producers: Sandeep Manohar, Pushkar Manohar, Language: Marathi (with English subtitles), 2017, 130 minutes.

The Marathi film Kanika, written and directed by Pushkar Manohar, has adopted a strange but effective approach to social evils like prenatal sex selection and sex selective abortions, without losing entertainment value.

Any healthy society must have a balanced sex ratio. But in India the alarmingly high rate of sex selective abortions is a cause for grave concern. Under the Indian Census of 2011, only 914 girls were born for every 1,000 boys in the age group 0-6 years. This is the worst child sex ratio in the history of our country since independence. This steep decline can be linked to the ever growing preference for a male child. The second largest state of the country, Maharashtra, has one of the worst child sex ratios among Indian states, where only 894 girls are born for every 1,000 boys. Preference for a male child due to oppressive customs like dowry is one of the most important reasons for the ever declining number of girls in Indian society. A contributory factor is the increased availability of advanced technologies, which are being misused to get rid of a girl child before birth. Even more heart-breaking is that girl children are being aborted by some qualified and unqualified doctors as a profitable business, due to which the whole medical fraternity is viewed with disgust. In March 2017, the police retrieved as many as nineteen female foetuses from a sewer in a village in western Maharashtra's Sangli district (1), dumped there by a doctor who practised such illegal abortions. In another infamous case from Beed (2), also in Maharashtra, it was revealed that the doctors involved were disposing of female foetuses by feeding them to dogs in order to destroy evidence.

The film, Kanika, explores the social horrors of such abortions, the patriarchal mindsets backing these actions, as well as the role of doctors in these social evils. The story revolves around the reputed Dr Kaushik Pradhan (played by Sharad Ponkshe) who runs a hospital and is involved in illegal prenatal sex determination and abortion, with the support of Dr Sachin (Nilesh Behre) and Dr Rashmi (Falguni Rajani). Dr Pradhan and his colleagues in crime start undergoing unusual paranormal experiences which shatter their day-to-day lives. These paranormal experiences become increasingly horrifying, affecting the protagonist's peace of mind. The tension mounts as the partners themselves get targeted. The secret is, of course, revealed in the climax. The film focuses on the misuse of medical knowledge and position.

This film also throws light on interesting facts and loopholes in medical practice. Performance wise, Sharad Ponkshe who plays Dr Pradhan, is able to convey a range of emotions from anger to fear, effortlessly. The performance of child artist, Kritina Vartak, who played the title role of Kanika, is really commendable. Other actors in supporting roles play their parts convincingly. Technically too, the film is good, with effective cinematography and a haunting background score that creates the atmosphere required for a horror film. In some scenes, you feel that the director has taken inspiration from some Hollywood horror classics, clear even from the film's posters! Sometimes the pace is too slow.

Overall, Kanika is a good film to watch, an excellent experiment where the horror genre is used to comment on the real horrors in society. At the end of the film, the legend on the screen "This is a work of fiction... reality is more horrific..." says everything. This film has a disturbing message for all of us, especially doctors who are involved in such heinous crimes.

\section{References:}

1. Times News Network. In Maharashtra's Sangli, 19 female fetuses found dumped. March 7, 2017[cited 2017 Sept 8]. Available from: http:// timesofindia.indiatimes.com/city/thane/in-maharashtras-sangli-19female-fetuses-found-dumped/articleshow/57487030.cms

2. Kumar K. Maharashtra: Doctors in Beed feed aborted female fetuses to dogs. India Today. 2012 May 23[cited 2017 Sep 8]. Available from: http:// indiatoday.intoday.in/story/doctors-in-beed-feed-aborted-femalefoetuses-to-dogs/1/189919.html

\footnotetext{
Author: Harshal Tukaram Pandve (drharshalpandve@gmail.com), Associate Professor, Department of Community Medicine, Smt Kashibai Navale Medical College, Narhe, Pune, 411 041, INDIA.

To cite: Pandve HT. A haunting message for unethical doctors. Indian J Med Ethics. 2018 Jan-Mar;3(1) NS: 74. DOI: 10.20529/JJME.2017.094

Published online on October 31, 2017.

Manuscript Editor: Sanjay A Pai

OIndian Journal of Medical Ethics 2017
} 